\title{
The value of transhumance for biodiversity conservation: Vulture foraging in relation to livestock movements
}

\author{
Natividad Aguilera-Alcalá (i), Eneko Arrondo, Roberto Pascual-Rico, \\ Zebensui Morales-Reyes, José M. Gil-Sánchez, José A. Donázar, \\ Marcos Moleón, José A. Sánchez-Zapata
}

Received: 28 July 2021 / Revised: 28 October 2021 / Accepted: 4 November 2021 / Published online: 7 December 2021

\begin{abstract}
In recent decades, intensive techniques of livestock raising have flourished, which has largely replaced traditional farming practices such as transhumance. These changes may have affected scavengers' behaviour and ecology, as extensive livestock is a key source of carrion. This study evaluates the spatial responses of avian scavengers to the seasonal movements of transhumant herds in south-eastern Spain. We surveyed the abundance of avian scavengers and ungulates, and analysed the factors affecting the space use by 30 GPS-tracked griffon vultures (Gyps fulvus). Griffons' foraging activity increased in the pasturelands occupied by transhumant herds, which implied greater vulture abundance at the landscape level during the livestock season. In contrast, facultative scavengers were more abundant without transhumant livestock herds, and the abundance of wild ungulates did not change in relation to livestock presence. We conclude that fostering transhumance and other traditional farming systems, to the detriment of farming intensification, could favour vulture conservation.
\end{abstract}

Keywords Farming intensification · GPS-tracking · Livestock - Traditional farming practices - Vultures . Wild ungulates

\section{INTRODUCTION}

Humans and scavengers have maintained a close and changing relationship since our origins (Moleón et al.

Supplementary Information The online version contains supplementary material available at https://doi.org/10.1007/s13280021-01668-x.
2014). With the first hunters and, especially, shepherds, humans became key carrion suppliers to scavenging animals, while scavengers provided humans with an important hygienic service by efficiently removing animal debris (Moleón et al. 2014). In particular, extensive livestock carcasses from traditional exploitations became a staple food source for vultures and other scavengers in many areas (Margalida et al. 2011), and even exceeded the contribution of wild ungulates (Margalida et al. 2018). Thus, traditional extensive livestock farming has helped to sustain scavenger populations in many regions of the world, such as Eurasian griffon vultures (Gyps fulvus; Parra and Tellería 2004) and Egyptian vultures (Neophron percnopterus; Mateo-Tomás and Olea 2010) in southwestern Europe.

However, the profound change in livestock products demand and management in the last few years could strongly influence scavenger behaviour and conservation. Both economic development and human population growth have led to an increasing demand in livestock products and a shift towards industrialization ("livestock revolution"; Seré et al. 2008). This change has involved the stabling of livestock (i.e. intensive farming) and a decline in extensive farming practices, particularly transhumance, which consists of the seasonal movement of herds to take advantage of the availability of natural pastures (Bunce et al. 2004). Transhumant livestock movement takes place twice a year, from wintering to summering areas and back, and is usually based on either latitudinal (north to south in the Northern Hemisphere) or altitudinal travels (generally, from mountains to lowland areas). There is evidence that this farming system has been practised in the Mediterranean region since the Neolithic (6000 years BC; Tejedor-Rodríguez et al. 2021). In Spain, a Mediterranean country with marked historic transhumance activity (MARM 2011), 
there were 3.5 million transhumant sheep in the eighteenth century, linked with Europe's wool demand and the Spanish monopoly on merino wool production (OterosRozas et al. 2013a). After the breakdown of this monopoly, transhumance underwent a continuous decline. Today, fewer than 0.5 million of the c. 15.5 million sheep in Spain perform transhumance (MAPA 2019). In parallel, the main market product of transhumant livestock has changed from wool to meat. Among the causes of the current decline of transhumant livestock numbers are the loss of economic profitability compared to intensive systems, rural abandonment and lack of generational relay (Oteros-Rozas et al. 2013a). In order to protect transhumance from disappearing, the Spanish government declared it to be a representative manifestation of intangible cultural heritage (Spanish Royal Decree 385/2017, of 8 April). The United Nations Educational, Scientific and Cultural Organization (UNESCO) also inscribed transhumance on the Representative List of the Intangible Cultural Heritage of Humanity in 2019 (https://ich.unesco.org/en/decisions/14.COM/10.B. 2).

Moreover, the abandonment of transhumance and other traditional livestock practices leads to landscape transformation. Lack of livestock grazing may entail vegetation succession, which promotes a landscape change from grassland to shrub and forest by means of a passive rewilding process (Navarro and Pereira 2015; Corlett 2016). Rewilding triggers an effect on the entire ecosystem, from primary producers to tertiary consumers, such as scavengers (Cortés-Avizanda et al. 2015). Shrub and forest landscape has favoured the expansion of wild ungulates in many European countries (Apollonio et al. 2010), such as Spain (Acevedo et al. 2011). However, for vultures and other avian scavengers, finding carcasses in more heterogeneous habitats with greater vegetation cover takes longer than in the open grazing areas occupied by livestock (Arrondo et al. 2019). In addition, intensive livestock farms substantially change the feeding paradigm for vertebrate scavengers by providing more predictable food in both space and time (Moleón et al. 2019). In turn, the food provided by these highly-predictable resources is of lowquality, as it contains veterinary drugs and other pollutants to which scavengers are exposed (Blanco et al. 2019). Thus, vultures inhabiting anthropized areas with intensive livestock farming have poorer physiological conditions (Gangoso et al. 2021) and lower survival rates due to human-cause mortality than those inhabiting more natural areas with more traditional farming systems (Arrondo et al. 2020a). Given vultures' poor conservation status worldwide (Ogada et al. 2012), investigating the livestock-vulture ecological relationship in the current scenario of rapid global environmental change is an urgent task.
Unlike most avian scavenger species, which are considered facultative or opportunistic scavengers, vultures are obligate scavengers (DeVault et al. 2003), which means that they completely rely on carrion to survive and reproduce. Thus, their foraging and distribution are greatly conditioned by carrion availability (Arrondo et al. 2018). Previous studies based on field surveys provided some evidence that vultures respond to the presence of transhumant livestock, with increased griffon vulture occurrence in roosts close to transhumant herds (Olea and MateoTomás 2009). However, vultures are extremely mobile species (Ruxton and Houston 2004), which challenges in depth investigation of causes and consequences of vulture movement. In recent years, there has been an increase in the use of GPS devices to track large bird movements (Alarcón and Lambertucci 2018). Thus, combining GPStracking techniques and field surveys could help to obtain a wide understanding of the ecological processes that shape vulture foraging, at spatial scales ranging from individuals to landscapes.

The present study aims to evaluate the space use by avian scavengers in response to the seasonal movements of transhumant herds in Sierra de Cazorla, Segura y Las Villas Natural Park (Spain), an area that houses the largest number of transhumant sheep in western Europe. To address this, we firstly explored the relationship between the abundance of avian scavengers (both obligate and facultative) and the abundance of wild and domestic ungulates at the landscape level, as inferred by field surveys. We secondly analysed the individual spatial responses of GPS-tracked griffon vultures to the presence and absence of transhumant herds. We focussed on the griffon vulture because it is the most abundant vulture species in Europe (Margalida et al. 2010) and the most efficient consumer of ungulate carcasses in Mediterranean habitats (Mateo-Tomás et al. 2017). Our general hypothesis is that avian scavengers, especially vultures, will arrange their space use according to carrion availability. In particular, we expect that vultures will increase their use of transhumant livestock areas in the season in which transhumant herds are present, while avian facultative scavengers will show a weaker response due to their reliance on alternative food sources.

\section{MATERIALS AND METHODS}

\section{Study area}

This study was carried out in one of Europe's largest protected areas (the Sierras de Cazorla, Segura y Las Villas Natural Park; $2143 \mathrm{~km}^{2}$ ), a mountain region in southeastern Spain. The climate is Mediterranean, with annual 
rainfall ranging between 300 and $1600 \mathrm{~mm}$, and a mean annual temperature of $12-16{ }^{\circ} \mathrm{C}$. The area is covered mainly by pine (Pinus halepensis, $P$. nigra, $P$. pinaster and $P$. sylvestris) and oak (Quercus ilex and $Q$. faginea) forests (Rivas-Martínez 1987). The natural park hosts a rich community of vertebrate scavengers. Obligate scavengers include four vulture species: three resident species (griffon, bearded Gypaetus barbatus and Egyptian vultures) and one species that is occasionally present (cinereous vultures Aegypius monachus) (Morales-Reyes et al. 2017). The griffon vulture is the most abundant vulture in this area, with more than 300 breeding pairs (Del Moral and Molina 2018). Major facultative scavengers include birds like golden eagles (Aquila chrysaetos), common ravens (Corvus corax), carrion crows (C. corone), Eurasian magpies (Pica pica) and Eurasian jays (Garrulus glandarius), and also mammals like red fox (Vulpes vulpes) and wild boar (Sus scrofa) (Arrondo et al. 2019). Apart from wild boar, the wild ungulates community includes red deer (Cervus elaphus), fallow deer (Dama dama), mouflon (Ovis orientalis) and Iberian ibex (Capra pyrenaica) (Martínez-Martínez 2002).

In the highest part of this natural park, there is a plateau called "Campos de Hernán Perea" (150 km²; 1600-1700 m a.s.1.; Fig. 1). This plateau is covered by communal pastures where transhumant herds from different lowland ranges in the Sierra Morena mountains (located 50-200 km away) arrive at the end of May and stay until the end of November (Morales-Reyes et al. 2018). This denotes two clearly delimited seasons in relation to the presence (JuneNovember; hereafter "livestock season") or absence of livestock (December-May; hereafter "no livestock season"). Transhumant herds include c. 35000 animals (Arrondo et al. 2019) (7\% of the total transhumant livestock in Spain; Oteros-Rozas et al. 2013a), mostly (> 90\%) sheep (Ovis aries), but also goats (Capra aegagrus hircus), cattle (Bos taurus) and horses (Equus ferus caballus).

\section{Abundance of avian scavengers, livestock and wild ungulates}

To determine if transhumance practices affect avian scavengers' space use, we assessed the differences in the abundance of avian scavengers (both obligate-vulturesand facultative scavengers-other raptors and corvids-) and ungulates (both domestic and wild species) between the seasons with and without transhumant livestock. For birds, we conducted 75 systematic 30-min point counts (for a similar approach, see Moleón et al. 2020). We surveyed 37 points during the livestock season (17 in SeptemberOctober 2019, 20 in July 2020) and 38 during the no livestock season (18 in January, 20 in February 2020). Point counts were separated by at least $1.2 \mathrm{~km}$ from one another (Fig. 1). Surveys were conducted with the help of binoculars $(\times 12)$ and field scopes (20-60x) from $2 \mathrm{~h}$ after sunrise to $2 \mathrm{pm}(\mathrm{UTC}+1)$ in winter and $3 \mathrm{pm}(\mathrm{UTC}+2)$ in summer to, thus, cover soaring birds' main active period (Vergara 2010). For each point count, we recorded the observed species and the number of observed individuals. To minimize recounting birds within and among points, we also recorded observation time, distance from the birds to the observer, and their flight direction (Bibby et al. 2000).

In order to quantify seasonal changes in the relative abundance of wild and domestic ungulates, we conducted 40 systematic 3-km-long transects (Putman et al. 2011): 20 during the livestock season (10 in September-October 2019, 10 in July 2020) and 20 during the no livestock season (10 in January, 10 in February 2020). Transects were done by walking on the unpaved roads distributed across the study area (Fig. 1). Transects were carried out at dawn or dusk when ungulates are more active (Pérez et al. 2014). For each transect, we recorded the observed species and number of individuals. To avoid double counting among transects, we also recorded observation time, location of the observed ungulates, and their direction, and their age and sex whenever possible. We expressed the relative abundance of both wild and domestic ungulates according to the Kilometric Abundance Index (KAI), i.e. the number of individuals observed per $\mathrm{km}$ walked (Vincent et al. 1991).

Both point counts and transects were distributed throughout the area mostly used by transhumant herds, i.e. the grassland plateau (Fig. 1). The average bird and ungulate abundances were calculated separately for each season (livestock and no livestock).

\section{Vulture GPS-tracking}

Using a baited cannon-net, we captured 30 adult griffon vultures in the natural park in December 2014. Each vulture was equipped with $90 \mathrm{~g}$ GPS/GPRS-GSM devices from e-obs digital telemetry (http://www.e-obs.de), which were attached using a backpack harness. These devices were configured according to weather conditions (see Table S1). Birds were monitored between January 2015 and December 2018, unless they died or the device technically failed (Table S2). All the individuals were sexed by molecular procedures (Wink et al. 1998). For each monitored year, the breeding status of all the tracked individuals was determined (breeding vs. non-breeding; see Table S2 for details) and the nest location of all the breeding birds. Breeding status was firstly identified by the accumulation of GPS fixes on cliffs suitable for nesting during vultures' nestling period (from March to August; Donázar 1993), and was then confirmed by field observations. The number of flying fixes (a proxy for foraging activity) located both 

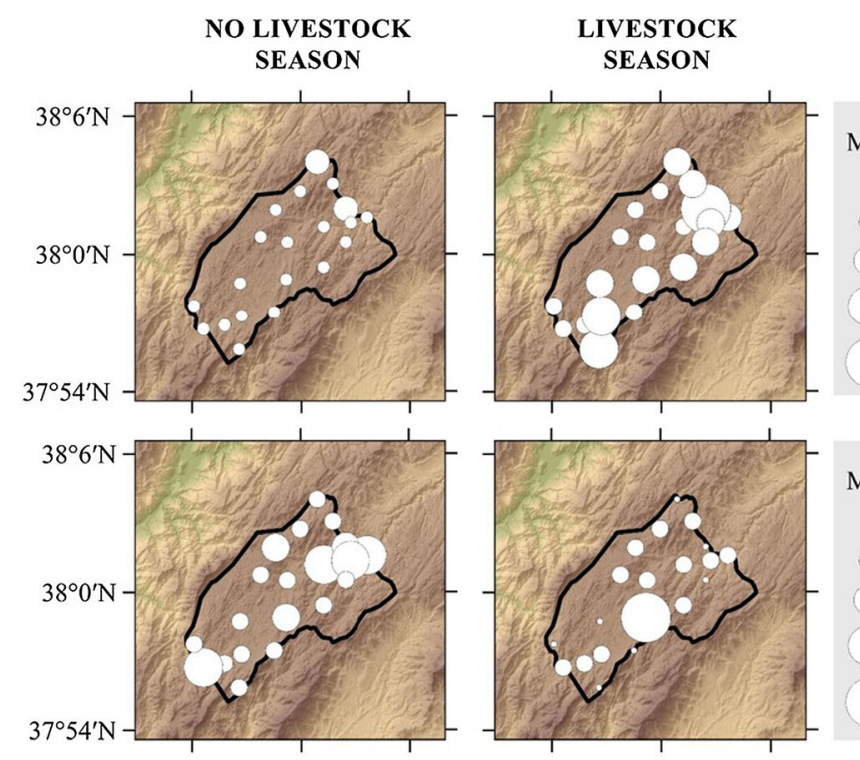

Median obligate scavengers observed

0

$1-25$

$26-60$

$61-100$

$101-154$
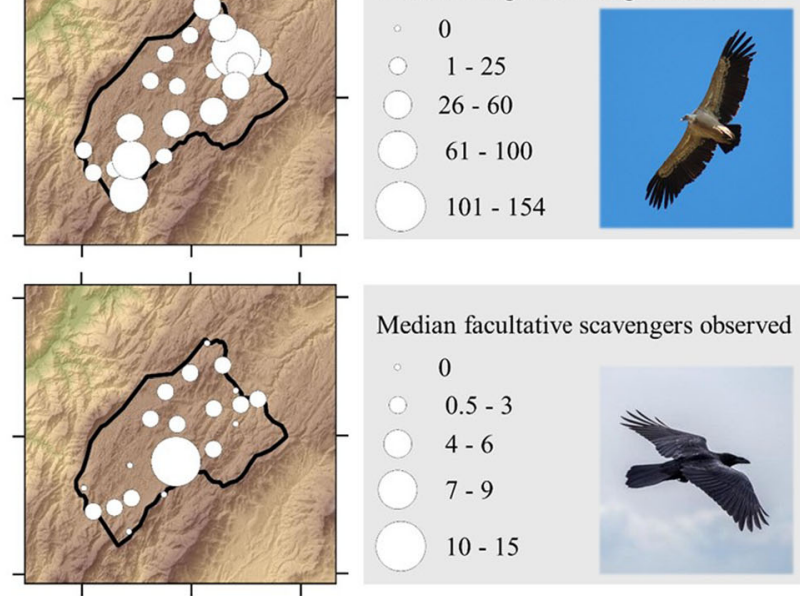

Median facultative scavengers observed

0

$0.5-3$

$4-6$

$7-9$

$10-15$
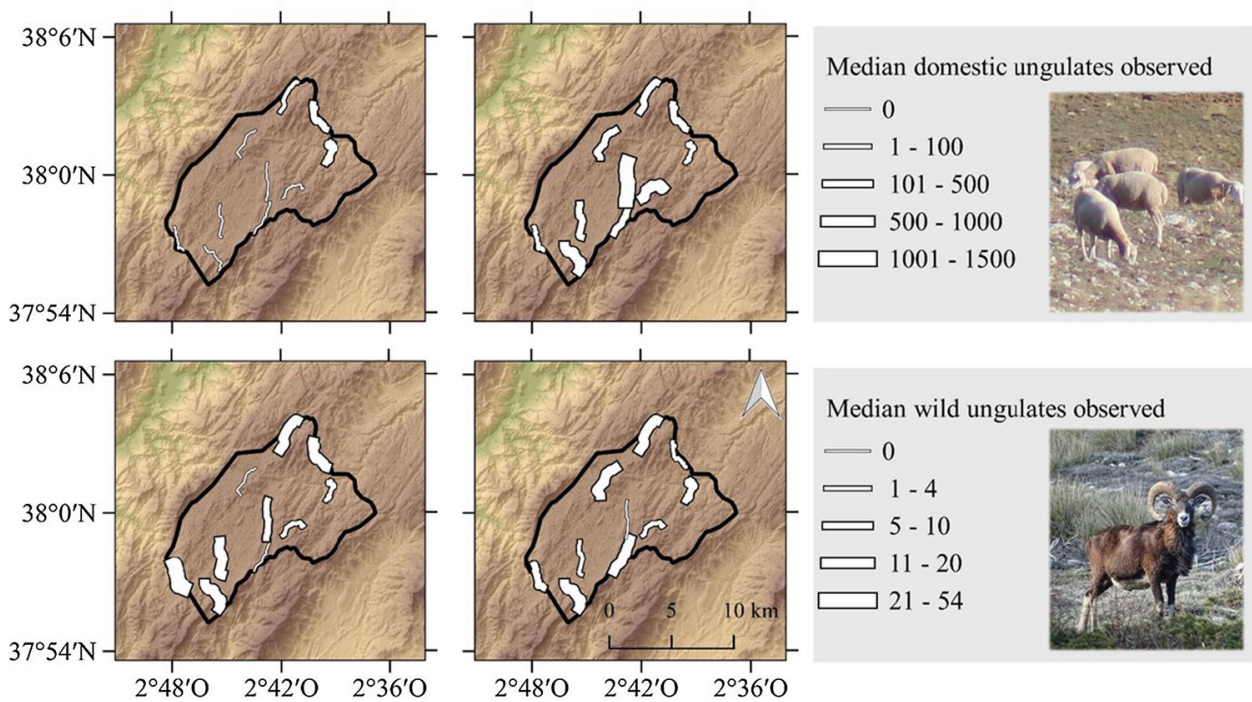

Fig. 1 Location of the study area (i.e. the high plateau called "Campos de Hernán Perea") in the Sierra de Cazorla, Segura y Las Villas Natural Park, south-eastern Spain. Point counts for avian scavengers and transects for ungulates are shown per season (livestock and no livestock). The size of the point counts (circles) and transects (lines) are proportional to the median number of observed individuals

inside and outside the plateau used by transhumant herds (see Fig. 1) was identified for this period. Flying fixes were considered those locations with a ground speed $>5 \mathrm{~m} / \mathrm{s}$ (see Arrondo et al. 2018 for more details).

\section{Statistical analyses}

We firstly used non-parametric Wilcoxon rank tests to explore changes in the abundance of avian scavengers and ungulates between seasons. The absence of normality in these variables was confirmed by the Shapiro-Wilk test $(\alpha=0.05)$.

In order to analyse the influence of transhumant herds on griffon vultures' use of the study area, we followed two different approaches: one focussed on the landscape level and another on the individual level. In the first approach, the aim was to explore whether griffon vultures were more frequently observed in the livestock area during the livestock season. For this purpose, we used generalized linear mixed models (GLMMs; Zuur et al. 2009) with Poisson error distributions and log link functions. We considered as response variable the "abundance" of griffon vultures observed per point count. The explanatory variables in the fixed term were the livestock "season" (yes/no) and the "nestling" period of griffon vultures (yes/no). To avoid pseudoreplication, we included "point" counts as a random term. We firstly constructed a full model with all the explanatory variables (no interactions among variables were considered due to low sample size). We secondly constructed the set of alternative models with different 
combinations of the random structure (i.e. one model with a "point" count as a random factor and another with no random term). We used the glmer() function of the lme4 package in $\mathrm{R}$ (Bates et al. 2015). We thirdly selected the model with the most appropriate random structure. Model selection was based on Akaike's Information Criterion (AIC). After selecting the most appropriate random structure (with a random term in our case), we selected the model with the most appropriate fixed structure by exploring the complete set of alternative models using the dredge() function of the MuMIn package in $\mathrm{R}$ (Barton 2013). The models with delta-AIC $<2$ in relation to the best model (i.e. the model with the lowest AIC) were considered to have similar support (Burnham and Anderson 2002). We finally explored candidate model's performance by means of marginal $R^{2}$, which measures how much variability in the response variable is explained by the model's fixed term (Nakagawa and Schielzeth 2013). For this purpose, we used the r.squaredGLMM() function of the MuMIn package in R (Barton 2013).

In the second approach, which aimed to assess individual griffon vulture foraging activity changes, we explored whether the GPS-tracked griffon vultures used the study area more during the livestock season, and which factors made some griffon vultures to use the area more than others. We applied GLMMs with binomial error distributions and logit link functions. We modelled the response variable as the proportional data with a binomial denominator of the total "GPS fixes" that fell within vs. beyond the study area limits each month per griffon vulture individual. The explanatory variables in the fixed term were livestock "season" (yes/no), "breeding" status (breeding/non-breeding), "sex" (male/ female) and "year" (as a factor, one for each tracked year). The individual ("ind.") was included as a random term. The process for model construction and selection, and for calculating the candidate models' performance, was like that described above.

All the analyses were done in R software, version 3.6.1 (R Core Team 2019) (https://cran.r-project.org/).

\section{RESULTS}

\section{Abundance of avian scavengers, livestock and wild ungulates}

Obligate scavengers were more abundant during the livestock season (Wilcoxon rank test $(p<0.05)$; Fig. 2). We observed avian scavengers in $95.9 \%$ of the point counts, and totalled 1728 observed birds (range: $0-154$ per point; mean \pm SD: $23.4 \pm 28.0$; Table 1$)$. We detected three species of obligate scavengers (griffon, black and bearded vultures) and five species of facultative scavengers. Griffon was by far the most abundant vulture $(89.1 \%$ of all the observed birds), with 1106 individuals observed during the livestock season and 434 during the no livestock season (Table 1). In general, vultures were c. 2.5 -fold more abundant during the livestock season than during the no livestock season (Fig. 2). In contrast, avian facultative scavengers were more abundant during the no livestock season (Fig. 2), with the carrion crow being the most frequently observed species, followed by common raven and golden eagle (Table 1).

Domestic ungulates were found in $55.0 \%$ of the transects, and totalled 10046 animals (range: 0-2228 per transect; mean \pm SD: $251.2 \pm 479.3$; Table 2). Sheep represented the bulk of the observed livestock species, followed far behind by goats. Cattle and horses were occasionally recorded. During the livestock season, domestic ungulates were c. 12-fold more abundant than during the no livestock season (Fig. 2). In contrast, wild ungulates were observed in more transects $(70.0 \%)$, but total abundance (418 individuals; range: $0-56$ per transect; mean \pm SD: $10.45 \pm 14.70$ ) was much lower than that of domestic ungulates, and was similar between seasons (Fig. 2). Mouflons were the most abundant species during both seasons, followed by red and fallow deer, Iberian ibex and wild boar (Table 2).

The GLMM with higher performance included livestock season (Table 3), and supported the notion that griffon vulture abundance increased during the livestock season (Table 4). According to $R^{2}$, season explained c. $33.0 \%$ of the variability in the number of observed griffon vultures on the plateau. Adding "nestling" period to the previous model did not improve $\mathrm{R}^{2}$ (Table 3 ), which suggests that the increased abundance of griffon vultures in the study area during the livestock season was not related to changes in breeder behaviour in relation to either the nesting season or movements of young vultures.

\section{Seasonal changes in the foraging areas of the GPS- tracked griffon vultures}

Griffon vultures tracking generated 11805 GPS fixes in the study area and 544429 outside it. According to the GLMM with higher performance, the proportion of inside vs. outside fixes depended on vulture breeding status, livestock season, sex, and year, as well as individual as random factor (Table 3). In particular, the proportion of GPS fixes inside the study area increased during the livestock season (Fig. 3), especially for non-breeding vultures and females, with some variation among years (Table 4). However according to $\mathrm{R}^{2}$, this model had low explanatory capacity (4\%), which became lower after excluding the variable "sex" (Table 4). During the livestock season, the proportion of GPS fixes inside vs. outside the study area increased for 19 individuals (c. 63\% of the GPS-tracked individuals; Fig. 3A). 

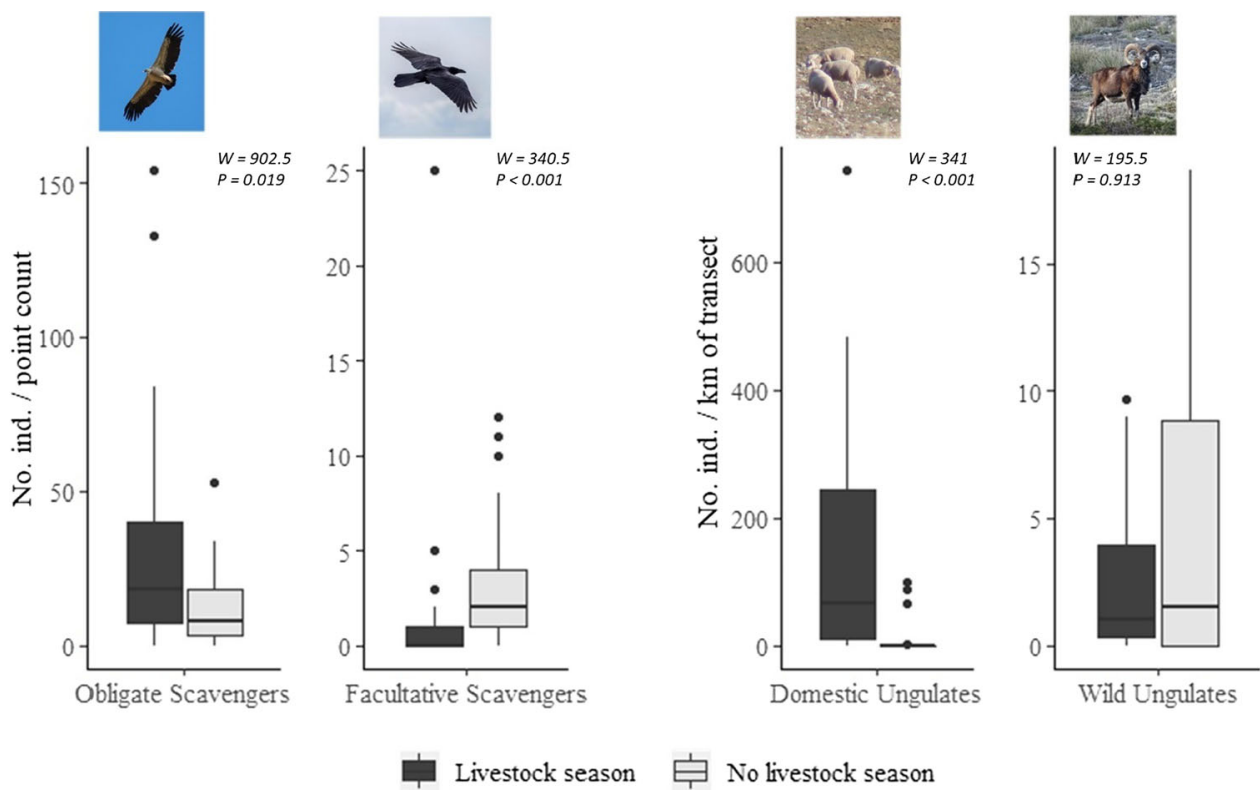

Livestock season

No livestock season

Fig. 2 Abundance comparisons of (obligate and facultative) avian scavengers and (domestic and wild species) ungulates between seasons (livestock vs. no livestock) in the study area. Boxes include from the first to the third data quartiles; the median is represented by a horizontal line; thin lines extend from the hinge to the largest and smallest value no further than $1.5 *$ IQR (the interquartile range); points show outliers. Differences between seasons were calculated by the non-parametric Wilcoxon rank test $(\alpha=0.05)$

Table 1 Results of the 30-min point counts conducted to survey avian scavengers' abundance in the study area according to season (livestock and no livestock)

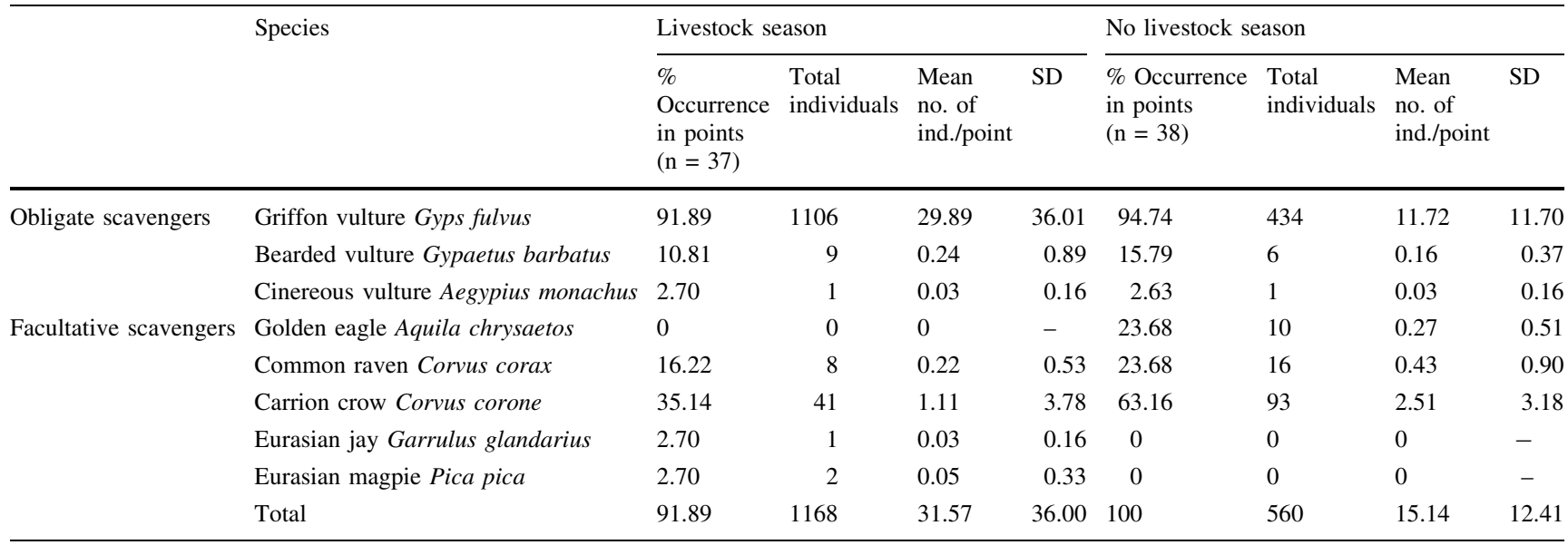

\section{DISCUSSION}

The results obtained from field observations and the GPStracked griffon vultures revealed that vulture (mostly griffons) abundance in the studied pastureland increased after transhumant herds had arrived. This agrees with previous research conducted in northern Spain, which found that the occurrence of griffon vultures increased at the roosting sites near transhumant sheep's summer pastures (Olea and Mateo-Tomás 2009). In contrast, the presence of transhumant livestock did not lead to an increase in the abundance of observed avian facultative scavengers. This was true even for species that frequently scavenge, such as the golden eagle, which is a regular carrion consumer in nearby Mediterranean mountains where griffon vultures are absent (Blázquez et al. 2009; Sánchez-Zapata et al. 2010). In the study area, however, golden eagles do not feed on livestock carcasses, likely because vultures quickly consume them (Arrondo et al. 2019). The high abundance of vultures here, especially 
Table 2 Results of the transects conducted to survey ungulates' abundance in the study area according to season (livestock and no livestock). KAI: Kilometric Abundance Index

\begin{tabular}{|c|c|c|c|c|c|c|c|}
\hline & \multirow[t]{2}{*}{ Species } & \multicolumn{3}{|l|}{ Livestock season } & \multicolumn{3}{|l|}{ No livestock season } \\
\hline & & $\begin{array}{l}\% \text { Occurrence in } \\
\text { transects }(n=20)\end{array}$ & $\begin{array}{l}\text { Total } \\
\text { individuals }\end{array}$ & KAI & $\begin{array}{l}\% \text { Occurrence in } \\
\text { transects }(n=20)\end{array}$ & $\begin{array}{l}\text { Total } \\
\text { individuals }\end{array}$ & KAI \\
\hline \multirow[t]{4}{*}{ Domestic } & Sheep Ovis aries & 70 & 9038 & 150.63 & 15 & 760 & 12.67 \\
\hline & Goat Capra aegagrus hircus & 35 & 194 & 2.73 & 5 & 1 & 0.02 \\
\hline & Cattle Bos Taurus & 10 & 42 & 0.70 & 5 & 2 & 0.03 \\
\hline & Horse Equus ferus caballus & 10 & 9 & 0.15 & 0 & 0 & 0 \\
\hline \multirow[t]{6}{*}{ Wild } & Mouflon Ovis orientalis & 55 & 113 & 1.88 & 50 & 195 & 3.25 \\
\hline & Red deer Cervus elaphus & 30 & 18 & 0.30 & 20 & 26 & 0.43 \\
\hline & Fallow deer Dama dama & 10 & 13 & 0.22 & 20 & 37 & 0.62 \\
\hline & Iberian ibex Capra pyrenaica & 10 & 2 & 0.03 & 5 & 1 & 0.02 \\
\hline & Wild boar Sus scrofa & 5 & 13 & 0.22 & 0 & 0 & 0 \\
\hline & Total & 100 & 9442 & 157.47 & 65 & 1022 & 17.03 \\
\hline
\end{tabular}

Table 3 Generalized linear mixed models (GLMMs) obtained from the AIC-based model selection to assess the factors influencing the changes in: (a) the number of griffon vultures observed in the study area per point count ("abundance"); (b) the GPS fixes per griffon vulture individual that fell within vs. beyond the study area limits ("GPS fixes"; see Methods for details on the explanatory variables)

\begin{tabular}{|c|c|c|c|c|c|}
\hline $\begin{array}{l}\text { Response } \\
\text { variable }\end{array}$ & Model & $\mathrm{k}$ & $\mathrm{AICc}$ & $\begin{array}{l}\text { delta- } \\
\text { AIC }\end{array}$ & $\mathrm{R}^{2}$ \\
\hline \multirow[t]{4}{*}{ Abundance } & season $+(1 \mid$ point $)$ & 1 & 1334.2 & $\mathbf{0}$ & $\mathbf{0 . 3 3 0}$ \\
\hline & season + nestling + (1|point $)$ & 2 & 1334.2 & 0.02 & 0.328 \\
\hline & nestling + (1lpoint $)$ & 1 & 1507.2 & 172.97 & \\
\hline & (1lpoint) & 0 & 1679.6 & 345.40 & \\
\hline \multirow[t]{16}{*}{ GPS fixes } & breeding + season + year $+(1 \mid$ ind. $)$ & 5 & 8468.5 & $\mathbf{0}$ & 0.014 \\
\hline & breeding + season + sex + year $+(1 \mid$ ind. $)$ & 6 & 8468.7 & 0.17 & 0.040 \\
\hline & season + year $+(1$ lind. $)$ & 4 & 8498.5 & 30.00 & \\
\hline & season + sex + year + (1lind. $)$ & 5 & 8499.1 & 30.55 & \\
\hline & breeding + year $+(1$ lind. $)$ & 4 & 8735.2 & 266.70 & \\
\hline & breeding + sex + year $+(1$ lind. $)$ & 5 & 8735.3 & 266.79 & \\
\hline & year + (1lind. $)$ & 3 & 8764.8 & 296.25 & \\
\hline & sex + year $+(1$ lind. $)$ & 4 & 8765.3 & 296.73 & \\
\hline & season + (1lind. $)$ & 1 & 8795.4 & 326.89 & \\
\hline & season $+\operatorname{sex}+(1$ lind. $)$ & 2 & 8796.0 & 327.48 & \\
\hline & breeding + season $+(1$ lind. $)$ & 2 & 8796.9 & 328.40 & \\
\hline & breeding + season + sex + (1lind. $)$ & 3 & 8797.5 & 328.95 & \\
\hline & (1lind.) & 0 & 9099.5 & 631.00 & \\
\hline & sex + (1lind.) & 1 & 9100.1 & 631.51 & \\
\hline & breeding + (1lind. $)$ & 1 & 9101.5 & 632.99 & \\
\hline & breeding + sex + (1lind. $)$ & 2 & 9102.0 & 633.51 & \\
\hline
\end{tabular}

Number of estimated parameters (k), AIC values, AIC differences (delta-AIC) with the highest ranked model (that with the lowest AIC) and the variability of the response variable explained by the predictors $\left(\mathrm{R}^{2}\right)$ are shown

Bold: the selected models 
Table 4 Selected generalized linear mixed models (GLMMs) showing the relation among season, nestling, breeding status and sex of griffon vultures, and year (see the text for details on the explanatory variables) and changes in: (a) the number of griffon vultures observed in the study area per point count ("abundance"); (b) the GPS fixes per griffon vulture individual that fell within vs. beyond the study area limits ("GPS fixes")

\begin{tabular}{|c|c|c|c|c|c|}
\hline Response variable & Model & Parameter & Estimate & SE & $\mathrm{df}$ \\
\hline \multirow[t]{5}{*}{ Abundance } & \multirow[t]{2}{*}{ Season + (1lpoint) } & Intercept & 2.188 & 0.161 & 3 \\
\hline & & Season (livestock) & 1.017 & 0.057 & \\
\hline & \multirow[t]{3}{*}{ Season + nestling $+(1$ point $)$} & Intercept & 2.194 & 0.161 & 4 \\
\hline & & Season (livestock) & 0.955 & 0.071 & \\
\hline & & Nestling (yes) & 0.097 & 0.065 & \\
\hline \multirow[t]{13}{*}{ GPS fixes } & \multirow[t]{6}{*}{ Breeding + season + year + (1lind. $)$} & Intercept & -5.161 & 0.357 & 7 \\
\hline & & Breeding (yes) & -0.325 & 0.057 & \\
\hline & & Season (livestock) & 0.412 & 0.026 & \\
\hline & & Year (2016) & 0.317 & 0.027 & \\
\hline & & Year (2017) & 0.357 & 0.028 & \\
\hline & & Year (2018) & -0.193 & 0.040 & \\
\hline & \multirow[t]{7}{*}{ Breeding + season + sex + year $+(1$ lind. $)$} & Intercept & -4.543 & 0.565 & 8 \\
\hline & & Breeding (yes) & -0.327 & 0.057 & \\
\hline & & Season (livestock) & 0.412 & 0.026 & \\
\hline & & Sex (male) & -0.981 & 0.712 & \\
\hline & & Year (2016) & 0.317 & 0.027 & \\
\hline & & Year (2017) & 0.357 & 0.028 & \\
\hline & & Year (2018) & -0.193 & 0.040 & \\
\hline
\end{tabular}

Only the models with the highest $\mathrm{R}^{2}$ are shown. The estimate of the parameters (including the sign), the standard error of the parameters (SE) and the degrees of freedom of the models (df) are shown

during the livestock season, could therefore prevent other less efficient scavengers from responding to transhumant herds, as found in other areas and with other carcass types (Sebastián-González et al. 2013; Morales-Reyes et al. 2017).

These seasonal differences in carrion availability were probably perceived by griffon vultures, as c. two thirds of the GPS-tracked individuals increased their use of the study area during the livestock season (Fig. 3). However, our models indicated high inter-individual variability, so there must be other variables associated with the tracked individuals that influenced their movement, such as carrion availability outside the study area. In fact, this area is very small (c. $150 \mathrm{~km}^{2}$ ) compared to the griffon vulture home range in southern Spain (average $=$ c. $11000 \mathrm{~km}^{2}$; Arrondo et al. 2020b). Though this small area congregates more than 35000 transhumant ungulates every summer, vultures may also find abundant food in many other areas within their home ranges (Arrondo et al. 2018, 2020b). For instance, Martin-Díaz et al. (2020) found that griffon vultures from south-eastern Spain widely forage in big game areas, feeding on wild ungulate carcasses from hunting activities. However, the main hunting season, which takes place in autumn-winter, overlaps only partially with the presence of transhumant herds in our study area. Outside the hunting season, griffon vultures greatly tend to forage in grasslands with abundant livestock (Martin-Díaz et al. 2020), as it is the case of our study area. Regardless, griffon vultures' observed individual response to transhumant livestock sufficed to trigger the above-mentioned strong seasonal variation in vulture abundance in the study area at the landscape level. An alternative, non-mutually exclusive explanation is that griffon vultures from other populations could also be attracted by transhumant herds to our study area, thus contributing to the increased vulture numbers there during the livestock season.

We also found that non-breeding and female griffon vultures were the individuals that responded the most to the presence of transhumant herds. On one hand, most of the griffon vultures observed using roosts near transhumant livestock in northern Spain were immature (Olea and Mateo-Tomás 2009). However, why breeding vultures respond less to an abundant food resource that is very close to their nesting sites is difficult to explain. On the other hand, griffon vultures have very slight sexual dimorphism (Xirouchakis and Poulakakis 2008) and share chick-rearing investment (Xirouchakis and Mylonas 2007). Thus, finding differences between sexes was an unexpected result. This contrasts to other vulture species with marked sexual dimorphism, such as Andean condors (Vultur gryphus), 
A

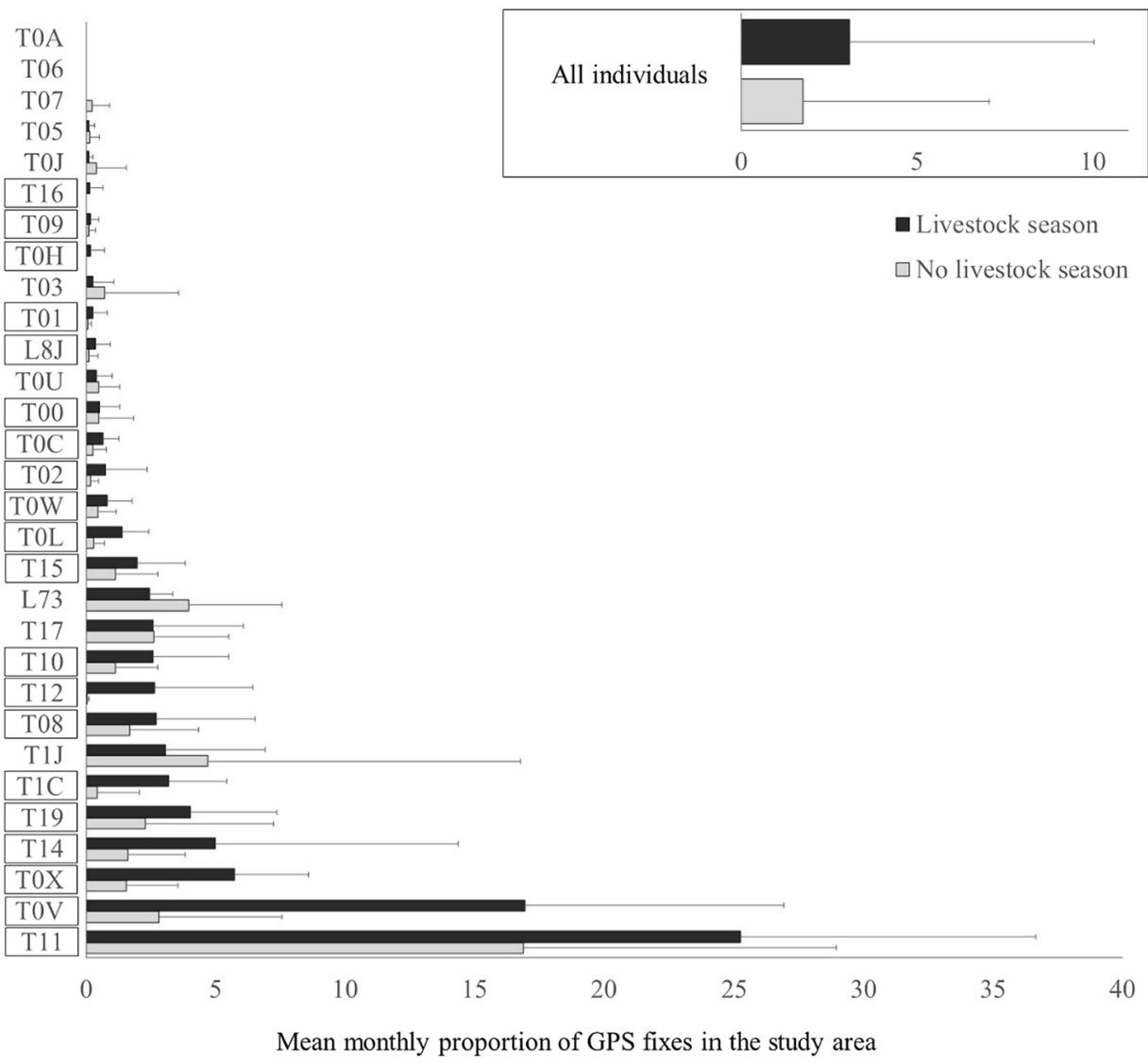

Fig. 3 GPS fixes of the tracked griffon vultures in the study area during the livestock and no livestock seasons per tracked individual (A) and for all the tracked individuals together $(\mathbf{B})$. Bars show the average of the monthly proportion of GPS fixes in relation to the total fixes; thin lines show the standard error. The individuals for which the proportion of fixes in the study area is higher during the livestock season than during the no livestock season are highlighted with boxes

which show different resource exploitation patterns (Perrig et al. 2021). However, recent studies suggest that sexpartitioning in resource exploitation on a fine scale should not be ruled out in griffons (Arrondo et al. 2020a, b). In any case, our results do not support a strong influence of the studied individual traits on griffon vulture responses to transhumant livestock.

Transhumance implies that the presence of domestic ungulates is drastically different between seasons. Although the seasonal absence of livestock could facilitate access of wild ungulates to the plateau after release from pasture competition, which occurs in other areas (Chirichella et al. 2014), our results showed that wild ungulates' seasonal abundance did not change seasonally. This might be due to the harsh climatic conditions in winter, which limits pasture availability in the plateau. In autumn-winter, some big game hunting takes place in the study area, which could make wild ungulates more cautious during this period. This generally means that when transhumant livestock leaves the plateau, carrion availability in the study area sharply declines, which leads to vultures' lower abundance and foraging activity.

Overall, our findings indicate that pasturelands with extensive livestock are important foraging areas for vultures. Although livestock farming has historically been involved in landscape transformation, extensive livestock farming might support high biodiversity values compared to intensive farming practices (Bernués et al. 2016). In particular, extensive farming modulates plant diversity in mountain pastures (Komac et al. 2014) and limits the vegetation succession in rewilding contexts (Riedel et al. 2013). Nevertheless, the global trend of increasing resources demand to supply the growing human population drives the intensification of production systems. Thus, the risk of traditional livestock practices, such as transhumance, being completely replaced with more intensive techniques in the near future is high, especially in developed countries. This may seriously compromise the sustainable development of human societies, as intensive farming demands high inputs of energy, water, and feed, which is linked to land degradation, water pollution, 
greenhouse gas emission, and, eventually, biodiversity loss (Ilea 2009). Thus, if the rewilding process is not properly managed, this situation could compromise not only vultures' conservation, but also the maintenance of other values associated with traditional activities, including local ecological knowledge (Oteros-Rozas et al. 2013b). In Mediterranean areas, the social stakeholders linked to extensive farming systems (e.g. shepherds) positively value scavengers' role (mostly vultures) as providers of ecosystem services (Cortés-Avizanda et al. 2018; Morales-Reyes et al. 2018). Therefore, loss of traditional practices as a result of disconnecting people from nature could imply a negative impact on the perception of the scavenger guild (Gigante et al. 2021) and a rise in harmful practices for scavengers, such as poisoning (Brink et al. 2021). Moreover, with the decline of extensive farming systems and the reduction of grassland areas in abandoned rural areas, scavenging birds will be driven to exploit resources in more anthropized landscapes, where the physiological condition and survival rates of vultures are lower (Arrondo et al. 2020b; Gangoso et al. 2021).

Until rewilding processes may lead to natural landscapes where wild ungulate carrion is made abundantly accessible to avian scavengers, it is essential for scavenger conservation to maintain extensive livestock farming against further development of intensive farming practices. This requires addressing the causes that are driving traditional farming systems towards extinction. Among them, the low profitability of the extensive livestock's product stands out as the main concern for Spanish farmers (Oteros-Rozas et al. 2013a). Hence, agro-economic policies need to be aimed at enhancing the market value of products by creating quality seals and effective publicity campaigns. In our study area, there is a system of public incentives, from both the European Union and regional administrations, that contributes to support transhumance, as well as an educational centre specialized in training young shepherds. These strategies have successfully helped to maintain a relatively important transhumant activity in this area, so they could also be implemented elsewhere. At the same time, intensive farming should be subject to stricter regulatory policies that allow minimize their multiple negative impacts on ecosystems and rural communities (Leip et al. 2015). Consequently, a more comprehensive understanding of the ecological consequences of abandoning traditional farming practices is crucial for environmental managers and policy makers to harmonize human activities and biodiversity in the current global ecological transition.

Acknowledgements P. Botella, L. Fernández-Gómez, M.I. García de la Fuente, A. Giménez, R. Palomar and M. Rincón-Madroñero helped during the fieldwork. Paloma Prieto, David Cuerda and the directors of Parque Natural de Cazorla, Segura y Las Villas helped with their assistance and the permits to conduct the fieldwork. This research was partially supported by the Spanish Ministry of Economy and Competitiveness (MINECO) and the European Regional Development Fund (ERDF; Project CGL2015-66966-C2-1-2-R and CGL201789905-R), the Spanish Ministry of Science, Innovation and Universities and ERDF (Project RTI2018-099609-B-C21, TRASCAR), and Junta de Andalucía (Projects RNM-1925 and P18-RT-132). In addition, the study was conducted in collaboration with and co-funded by the Yolda Initiative and the Asociación Trashumancia y Naturaleza, with support from the MAVA Foundation. N.A-A. was supported by a pre-doctoral grant (BES-2016-077351) from the MINECO and the European Social Fund (ESF), Z.M.-R. by a postdoctoral contract cofunded by the Generalitat Valenciana and the ESF (APOSTD/2019/ 016), R.P-R. by a postdoctoral grant from the UCLM (Plan Propio de I+D+I, 2021), and M.M. by a Ramón y Cajal research contract (RYC-2015-19231).

Funding Open Access funding provided thanks to the CRUE-CSIC agreement with Springer Nature.

Open Access This article is licensed under a Creative Commons Attribution 4.0 International License, which permits use, sharing, adaptation, distribution and reproduction in any medium or format, as long as you give appropriate credit to the original author(s) and the source, provide a link to the Creative Commons licence, and indicate if changes were made. The images or other third party material in this article are included in the article's Creative Commons licence, unless indicated otherwise in a credit line to the material. If material is not included in the article's Creative Commons licence and your intended use is not permitted by statutory regulation or exceeds the permitted use, you will need to obtain permission directly from the copyright holder. To view a copy of this licence, visit http://creativecommons. org/licenses/by/4.0/.

\section{REFERENCES}

Acevedo, P., M.Á. Farfán, A.L. Márquez, M. Delibes-Mateos, R. Real, and J.M. Vargas. 2011. Past, present and future of wild ungulates in relation to changes in land use. Landscape Ecology 26: 19-31. https://doi.org/10.1007/s10980-010-9538-2.

Alarcón, P.A.E., and S.A. Lambertucci. 2018. A three-decade review of telemetry studies on vultures and condors. Movement Ecology. https://doi.org/10.1186/s40462-018-0133-5.

Apollonio, M., R. Andersen, R. Putman (2010) European ungulates and their management in the 21 st century, edited by $\mathrm{M}$. Apollonio, R. Andersen, R. Putman. Cambridge: Cambridge University Press.

Arrondo, E., M. Moleón, A. Cortés-Avizanda, J. Jiménez, P. Beja, J.A. Sánchez-Zapata, and J.A. Donázar. 2018. Invisible barriers: Differential sanitary regulations constrain vulture movements across country borders. Biological Conservation 219: 46-52. https://doi.org/10.1016/j.biocon.2017.12.039.

Arrondo, E., Z. Morales-Reyes, M. Moleón, A. Cortés-Avizanda, J.A. Donázar, and J.A. Sánchez-Zapata. 2019. Rewilding traditional grazing areas affects scavenger assemblages and carcass consumption patterns. Basic and Applied Ecology 41: 56-66. https:// doi.org/10.1016/j.baae.2019.10.006.

Arrondo, E., J. Navarro, J.M. Perez-García, R. Mateo, P.R. Camarero, R.C.R. Martin-Doimeadios, M. Jiménez-Moreno, A. CortésAvizanda, et al. 2020a. Dust and bullets: Stable isotopes and GPS tracking disentangle lead sources for a large avian scavenger. Environmental Pollution. https://doi.org/10.1016/j. envpol.2020.115022. 
Arrondo, E., A. Sanz-Aguilar, J.M. Pérez-García, A. CortésAvizanda, J.A. Sánchez-Zapata, and J.A. Donázar. 2020. Landscape anthropization shapes the survival of a top avian scavenger. Biodiversity and Conservation. https://doi.org/10. 1007/s10531-020-01942-6.

Barton, K. 2013. MuMIn: Multi-model interference. $R$ Package Version 1 (9): 13

Bates, D., M. Martin, B. Bolker, and S. Walker. 2015. Fitting linear mixed-effects models using lme4. Journal of Statistical Software 67: 1-48. https://doi.org/10.18637/jss.v067.i01.

Bernués, A., E. Tello-García, T. Rodríguez-Ortega, R. Ripoll-Bosch, and I. Casasús. 2016. Agricultural practices, ecosystem services and sustainability in high nature value farmland: Unraveling the perceptions of farmers and nonfarmers. Land Use Policy 59: 130-142. https://doi.org/10.1016/j.landusepol.2016.08.033.

Bibby, C.J., N.D. Burgess, D.M. Hillis, D.A. Hill, and S. Mustoe. 2000. Bird Census Techniques, 2nd ed. London: Elsevier.

Blanco, G., A. Cortés-Avizanda, Ó. Frías, E. Arrondo, and J.A. Donázar. 2019. Livestock farming practices modulate vulture diet-disease interactions. Global Ecology and Conservation 17: e00518. https://doi.org/10.1016/j.gecco.2018.e00518.

Blázquez, M., J.A. Sánchez-Zapata, F. Botella, M. Carrete, and S. Eguía. 2009. Spatio-temporal segregation of facultative avian scavengers at ungulate carcasses. Acta Oecologica 35: 645-650. https://doi.org/10.1016/j.actao.2009.06.002.

Brink, C.W., R.L. Thomson, A. Amar, M. Girardello, and A. Santangeli. 2021. Prevalence and drivers of poison use by South African commercial farmers and perceptions of alternative livestock protection measures. Ambio 50: 1211-1221. https:// doi.org/10.1007/s13280-020-01461-2.

Bunce, R. G. H., M. Pérez-Soba, R. H. Jongman, A. Gómez Sal, F. Herzog, and I. Austad. 2004. Transhumance and Biodiversity in European Mountains, Report of the EU-FP5 project TRANSHUMOUNT (EVK2-CT-2002-80017). Edited by R.G.H. Bunce, M. Pérez-Soba, R.H.G Jongman, A. Gómez Sal, F. Herzog, and I. Austad. Alterra and IALE.

Burnham, K.P., and D.R. Anderson. 2002. Model Selection and Multimodel Inference A Practical Information-Theoretic Approach 2. Berlin: Springer.

Chirichella, R., M. Apollonio, and R. Putman. 2014. Competition between domestic and wild and wild ungulates. In Behaviour and Management of European Ungulates, ed. R. Putman, 110-123. Caithness: Whittles Publishing.

Corlett, R.T. 2016. The role of rewilding in landscape design for conservation. Current Landscape Ecology Reports 1: 127-133. https://doi.org/10.1007/s40823-016-0014-9.

Cortés-Avizanda, A., J.A. Donázar, and H.M. Pereira. 2015. Top scavengers in a wilder Europe. In Rewilding European Landscapes, ed. H.M. Pereira and L.M. Navarro, 85-106. Berlin: Springer International Publishing. https://doi.org/10.1007/978-3319-12039-3 5.

Cortés-Avizanda, A., B. Martín-López, O. Ceballos, and H.M. Pereira. 2018. Stakeholders perceptions of the endangered Egyptian vulture: Insights for conservation. Biological Conservation 218: 173-180. https://doi.org/10.1016/j.biocon.2017.09. 028.

Del Moral, J.C., and B. Molina. 2018. El buitre Leonado en España, población reproductora en 2018 y método de censo. Madrid: SEO/BirdLife ((in Spanish)).

DeVault, T.L., O.E. Rhodes, and J.A. Shivik. 2003. Scavenging by vertebrates: Behavioral, ecological, and evolutionary perspectives on an important energy transfer pathway in terrestrial ecosystems. Oikos 102: 225-234. https://doi.org/10.1034/j.16000706.2003.12378.x.

Donázar, J.A. 1993. Los buitres ibéricos: biología y conservación. Madrid: JM Reyero (in Spanish).
Gangoso, L., A. Cortés-Avizanda, A. Sergiel, B. Pudifoot, F. Miranda, J. Muñoz, A. Delgado-González, M. Moleón, et al. 2021. Avian scavengers living in anthropized landscapes have shorter telomeres and higher levels of glucocorticoid hormones. Science of the Total Environment 782: 146920. https://doi.org/ 10.1016/j.scitotenv.2021.146920.

Gigante, F.D., J.P.V. Santos, J.V. López-Bao, P.P. Olea, B. Verschuuren, and P. Mateo-Tomás. 2021. Farmers' perceptions towards scavengers are influenced by implementation deficits of EU sanitary policies. Biological Conservation 259: 109166. https://doi.org/10.1016/j.biocon.2021.109166.

Ilea, R.C. 2009. Intensive livestock farming: Global trends, increased environmental concerns, and ethical solutions. Journal of Agricultural and Environmental Ethics 22: 153-167. https:// doi.org/10.1007/s10806-008-9136-3.

Komac, B., M. Domènech, and R. Fanlo. 2014. Effects of grazing on plant species diversity and pasture quality in subalpine grasslands in the eastern Pyrenees (Andorra): Implications for conservation. Journal for Nature Conservation 22: 247-255. https://doi.org/10.1016/j.jnc.2014.01.005.

Leip, A., G. Billen, J. Garnier, B. Grizzetti, L. Lassaletta, S. Reis, D. Simpson, M.A. Sutton, et al. 2015. Impacts of European livestock production: Nitrogen, sulphur, phosphorus and greenhouse gas emissions, land-use, water eutrophication and biodiversity. Environmental Research Letters 10: 115004. https://doi. org/10.1088/1748-9326/10/11/115004.

Margalida, A., J.A. Donázar, M. Carrete, and J.A. Sánchez-Zapata. 2010. Sanitary versus environmental policies: Fitting together two pieces of the puzzle of European vulture conservation. Journal of Applied Ecology 47: 931-935. https://doi.org/10. 1111/j.1365-2664.2010.01835.x.

Margalida, A., M.À. Colomer, and D. Sanuy. 2011. Can wild ungulate carcasses provide enough biomass to maintain avian scavenger populations? An empirical assessment using a bio-inspired computational model. PLOS ONE 6: e20248. https://doi.org/10. 1371/journal.pone.0020248.

Margalida, A., P. Oliva-Vidal, A. Llamas, and M.À. Colomer. 2018. Bioinspired models for assessing the importance of transhumance and transboundary management in the conservation of European avian scavengers. Biological Conservation 228: 321-330. https://doi.org/10.1016/j.biocon.2018.11.004.

MARM (Ministerio de Medio Ambiente y Medio Rural y Marino). 2011. Libro Blanco de la transhumancia. Edited by Ministerio de Medio Ambiente y Medio Rural y Marino. Madrid: Dirección de Desarrollo Sostenible del Medio Rural, Ministerio del Medio Ambiente, y Medio Rural y Marino (in Spanish).

Martin-Díaz, P., A. Cortés-Avizanda, D. Serrano, E. Arrondo, J.A. Sánchez-Zapata, and J.A. Donázar. 2020. Rewilding processes shape the use of Mediterranean landscapes by an avian top scavenger. Scientific Reports 10: 1-12. https://doi.org/10.1038/ s41598-020-59591-2.

Martínez-Martínez, T. 2002. Comparison and overlap of sympatric wild ungulate diet in Cazorla, Segura y Las Villas Natural Park. Pirineos 157: 103-115. https://doi.org/10.3989/pirineos.2002. v157.65.

Mateo-Tomás, P., and P.P. Olea. 2010. Diagnosing the causes of territory abandonment by the endangered Egyptian vulture Neophron percnopterus: The importance of traditional pastoralism and regional conservation. Oryx 44: 424-433. https://doi. org/10.1017/S0030605310000189.

Mateo-Tomás, P., P.P. Olea, M. Moleón, N. Selva, and J.A. SánchezZapata. 2017. Both rare and common species support ecosystem services in scavenger communities. Global Ecology and Biogeography 26: 1459-1470. https://doi.org/10.1111/geb.12673.

Ministerio de Agricultura Pesca y Alimentación. 2019. Efectivos y producciones ganaderas. 8.1.4.2. Efectivos ganaderos-ganado 
ovino:analisis provincial del número de animales según tipos, 2019 (Noviembre) (in Spanish).

Moleón, M., J.A. Sánchez-Zapata, A. Margalida, M. Carrete, N. Owen-Smith, and J.A. Donázar. 2014. Humans and scavengers: The evolution of interactions and ecosystem services. BioScience 64: 394-403. https://doi.org/10.1093/biosci/biu034.

Moleón, M., N. Selva, M.M. Quaggiotto, D.M. Bailey, A. CortésAvizanda, and T.L. DeVault. 2019. Carrion availability in space and time. In Carrion Ecology and Management, ed. P.P. Olea, P. Mateo-Tomás, and J.A. Sánchez-Zapata, 23-44. Cham: Springer International Publishing. https://doi.org/10.1007/978-3-03016501-7_2.

Moleón, M., A. Cortés-Avizanda, J.M. Pérez-García, J. Bautista, C. Geoghegan, M. Carrete, A. Amar, J.A. Sánchez-Zapata, et al. 2020. Distribution of avian scavengers inside and outside of protected areas: Contrasting patterns between two areas of Spain and South Africa. Biodiversity and Conservation 29: 3349-3368. https://doi.org/10.1007/s10531-020-02027-0.

Morales-Reyes, Z., J.A. Sánchez-Zapata, E. Sebastián-González, F. Botella, M. Carrete, and M. Moleón. 2017. Scavenging efficiency and red fox abundance in Mediterranean mountains with and without vultures. Acta Oecologica 79: 81-88. https://doi.org/ 10.1016/j.actao.2016.12.012.

Morales-Reyes, Z., B. Martín-López, M. Moleón, P. Mateo-Tomás, F. Botella, A. Margalida, J.A. Donázar, G. Blanco, et al. 2018. Farmer perceptions of the ecosystem services provided by scavengers: What, who, and to whom. Conservation Letters 11: 1-11. https://doi.org/10.1111/conl.12392.

Nakagawa, S., and H. Schielzeth. 2013. A general and simple method for obtaining R2 from generalized linear mixed-effects models. Methods in Ecology and Evolution 4: 133-142. https://doi.org/ 10.1111/j.2041-210x.2012.00261.x.

Navarro, L.M., and H.M. Pereira. 2015. Rewilding abandoned landscapes in Europe. In Rewilding European Landscapes, ed. H.M. Pereira and L.M. Navarro, 3-23. Berlin: Springer International Publishing. https://doi.org/10.1007/978-3-319-12039-3_ 1.

Ogada, D.L., F. Keesing, and M.Z. Virani. 2012. Dropping dead: Causes and consequences of vulture population declines worldwide. Annals of the New York Academy of Sciences 1249: 57-71. https://doi.org/10.1111/j.1749-6632.2011.06293.x.

Olea, P.P., and P. Mateo-Tomás. 2009. The role of traditional farming practices in ecosystem conservation: The case of transhumance and vultures. Biological Conservation 142: 1844-1853. https:// doi.org/10.1016/j.biocon.2009.03.024.

Oteros-Rozas, E., B. Martín-López, C.A. López, I. Palomo, and J.A. González. 2013a. Envisioning the future of transhumant pastoralism through participatory scenario planning: A case study in Spain. The Rangeland Journal 35: 251-272. https://doi.org/10. 1071/RJ12092.

Oteros-Rozas, E., R. Ontillera-Sánchez, P. Sanosa, E. GómezBaggethun, and V. Reyes-García. 2013b. Traditional ecological knowledge among transhumant pastoralists in Mediterranean Spain. Ecology and Society. https://doi.org/10.5751/ES-05597180333.

Parra, J., and J.L. Tellería. 2004. The increase in the Spanish population of Griffon Vulture Gyps fulvus during 1989-1999: Effects of food and nest site availability. Bird Conservation International 14: 33-41. https://doi.org/10.1017/ S0959270904000048.

Pérez, J.M., M. Sarasa, G. Moço, J.E. Granados, J.P. Crampe, E. Serrano, L. Maurino, P.G. Meneguz, et al. 2014. The effect of data analysis strategies in density estimation of mountain ungulates using distance sampling. Italian Journal of Zoology 82: 262-270. https://doi.org/10.1080/11250003.2014.974695.
Perrig, P.L., S.A. Lambertucci, P.A.E. Alarcón, A.D. Middleton, J. Padró, P.I. Plaza, G. Blanco, J.A. Sánchez-Zapata, et al. 2021. Limited sexual segregation in a dimorphic avian scavenger, the Andean condor. Oecologia 196: 77-88. https://doi.org/10.1007/ s00442-021-04909-8.

Putman, R., M. Apollonio, and R. Andersen. 2011. Ungulate Management in Europe: Problems and Practices. Cambridge: Cambridge University Press.

R Core Team. 2019. R: A Language and Environment for Statistical Computing. Vienna, Austria: R Foundation for Statistical Computing.

Riedel, J.L., A. Bernués, and I. Casasús. 2013. Livestock grazing impacts on herbage and shrub dynamics in a Mediterranean Natural Park. Rangeland Ecology \& Management 66: 224-233. https://doi.org/10.2111/REM-D-11-00196.1.

Rivas-Martínez, S. 1987. Mapa de las Series de Vegetación de España. Madrid: ICONA ((in Spanish)).

Ruxton, G.D., and D.C. Houston. 2004. Obligate vertebrate scavengers must be large soaring fliers. Journal of Theoretical Biology 228: 431-436. https://doi.org/10.1016/j.jtbi.2004.02.005.

Sánchez-Zapata, J.A., S. Eguía, M. Blázquez, M. Moleón, and F. Botella. 2010. Unexpected role of ungulate carcasses in the diet of Golden Eagles Aquila chrysaetos in Mediterranean mountains. Bird Study 57: 352-360. https://doi.org/10.1080/ 00063651003674946.

Sebastián-González, E., J.A. Sánchez-Zapata, J.A. Donázar, N. Selva, A. Cortés-Avizanda, F. Hiraldo, M. Blázquez, F. Botella, et al. 2013. Interactive effects of obligate scavengers and scavenger community richness on lagomorph carcass consumption patterns. Ibis 155: 881-885. https://doi.org/10.1111/ibi.12079.

Seré, C., A. van der Zijpp, G. Persley, and E. Rege. 2008. Dynamics of livestock production systems, drivers of change and prospects for animal genetic resources. Animal Genetic Resources Information 42: 3-24. https://doi.org/10.1017/s1014233900002510.

Tejedor-Rodríguez, C., M. Moreno-García, C. Tornero, A. Hoffmann, Í. García-Martínez de Lagrán, H. Arcusa-Magallón, R. GarridoPena, J.I. Royo-Guillén, et al. 2021. Investigating Neolithic caprine husbandry in the Central Pyrenees: Insights from a multi-proxy study at Els Trocs cave (Bisaurri, Spain). PLoS ONE 16: e0244139. https://doi.org/10.1371/journal.pone.0244139.

Vergara, P. 2010. Time-of-day bias in diurnal raptor abundance and richness estimated by road surveys. Revista Catalana D'ornitologia 26: 22-30.

Vincent, J.-P., J.-M. Gaillard, and E. Bideau. 1991. Kilometric index as biological indicator for monitoring forest roe deer populations. Acta Theriologica 36: 315-328.

Wink, M., H. Sauer-Gürth, F. Martinez, G. Doval, G. Blanco, and O. Hatzofe. 1998. The use of (GACA)4 PCR to sex old world vultures (Aves: Accipitridae). Molecular Ecology 7: 779-782. https://doi.org/10.1046/j.1365-294x.1998.00377.x.

Xirouchakis, S.M., and N. Poulakakis. 2008. Biometrics, sexual dimorphism and gender determination of Griffon Vultures Gyps fulvus from Crete. Ardea 96: 91-98. https://doi.org/10.5253/078. 096.0110.

Xirouchakis, S.M., and M. Mylonas. 2007. Breeding behaviour and parental care in the griffon vulture Gyps fulvus on the Island of Crete (Greece). Ethology Ecology and Evolution 19: 1-26. https://doi.org/10.1080/08927014.2007.9522578.

Zuur, A., E.N. Leno, N. Walker, A.A. Saveliev, and G.M. Smith. 2009. Mixed Effects Models and Extensions in Ecology with R. New York: Springer.

Publisher's Note Springer Nature remains neutral with regard to jurisdictional claims in published maps and institutional affiliations. 


\section{AUTHOR BIOGRAPHIES}

Natividad Aguilera-Alcalá $(\square)$ is a doctoral candidate at the Miguel Hernández University. Her research interest includes conservation scavengers and ecosystem services.

Address: Department of Applied Biology, Miguel Hernández University, 03202 Elche, Spain.

Address: Centro de Investigación e Innovación Agroalimentaria y Agroambiental (CIAGRO-UMH), Miguel Hernández University, Elche, Spain.

e-mail: naguilera@umh.es

Eneko Arrondo is a postdoctoral researcher at the Miguel Hernández University. His research interest includes movement ecology of avian scavengers and carrion ecology at individual, population and community scale.

Address: Department of Applied Biology, Miguel Hernández University, 03202 Elche, Spain.

Address: Centro de Investigación e Innovación Agroalimentaria y Agroambiental (CIAGRO-UMH), Miguel Hernández University, Elche, Spain.

Address: Department of Conservation Biology, EBD-CSIC, 41092 Seville, Spain.

e-mail: bioeaf@gmail.com

Roberto Pascual-Rico is a postdoctoral researcher at the Research Institute of Hunting Resources (IREC - CSIC, UCLM, JCCM). His research interest includes ecology and ecosystem services of wild ungulates.

Address: Research Institute of Hunting Resources (IREC - CSIC, UCLM, JCCM), 13005 Ciudad Real, Spain.

e-mail: robe.amb@gmail.com

Zebensui Morales-Reyes is a postdoctoral researcher at the Miguel Hernández University. His research interest includes ecology and conservation of vertebrates and the study of socio-ecological systems. Address: Department of Applied Biology, Miguel Hernández University, 03202 Elche, Spain.
Address: Centro de Investigación e Innovación Agroalimentaria y Agroambiental (CIAGRO-UMH), Miguel Hernández University, Elche, Spain.

e-mail: zmorales@umh.es

José M. Gil-Sánchez is an associate researcher at Miguel Hernández University. His research interest includes biodiversity conservation and ecology of endangered wildlife.

Address: Department of Applied Biology, Miguel Hernández University, 03202 Elche, Spain.

e-mail: jmgilsanchez@yahoo.es

José A. Donázar is a research professor at Estación Biológica de Doñana. His research interest includes population and conservation ecology of long-lived vertebrates.

Address: Department of Conservation Biology, EBD-CSIC, 41092 Seville, Spain.

e-mail: donazar@ebd.csic.es

Marcos Moleón is a Ramon y Cajal researcher at the University of Granada. His research mainly focusses on the ecology and conservation of large predators and scavengers.

Address: Department of Zoology, University of Granada, 18071 Granada, Spain.

e-mail: mmoleonpaiz@hotmail.com

José A. Sánchez-Zapata is full professor at Miguel Hernández University. His research interest includes the relationship between biodiversity and ecosystem functioning and their applications to nature conservation.

Address: Department of Applied Biology, Miguel Hernández University, 03202 Elche, Spain.

Address: Centro de Investigación e Innovación Agroalimentaria y Agroambiental (CIAGRO-UMH), Miguel Hernández University, Elche, Spain.

e-mail: toni@umh.es 